\title{
Providing Appropriate Solutions for Treatment and Sewage of Wastewaters in Cargo Terminals of Shorelines: An Emphasis on Terminal Bandar
}

\author{
Gholamreza Mansourri \\ Science in Environmental Engineering, Islamic Azad University, Tehran, Iran \\ Email: gr.reza.m@gmail.com
}

Received 21 December 2015; accepted 23 January 2016; published 26 January 2016

Copyright (C) 2016 by author and Scientific Research Publishing Inc.

This work is licensed under the Creative Commons Attribution International License (CC BY).

http://creativecommons.org/licenses/by/4.0/

(c) (i)

\begin{abstract}
Low volume of produced wastewater and specific regional, environmental and economic condition in small communities determines the methods of treatment of sewage in such communities including shorelines of Bandar Abbas, Bushehr, Imam Khomeini Harbor and Chabahar Harbor. Ineffective methods of treating and sewing wastewater in aforesaid terminals as well as limitations of methods of wastewater treatment such as high level of underground waters doubled the necessity of considering alternative methods. In this paper, investigation of current conditions was performed through field observations and data collection regarding wastewater production in terminals and determination of qualitative specifications using sampling and carrying out $\mathbf{p H}$, TSS, COD, BOD and temperature tests from inlet to outlet of available sewage system of abovementioned terminals and comparison with environmental organization standards corresponding to wastewater sewage and it was found out that conditions of available systems of wastewater treatment are not suitable. In this regard, modifying solutions for the sake of improving performance of systems of wastewater treatment of terminals is presented in this research. Finally, for wastewater treatment system of Bandar Abbas terminal, if there is no limitation for allocating lands, it is recommended to use artificial canebrake system with underground flow.
\end{abstract}

\section{Keywords}

Cargo Terminal, Wastewater, Wastewater Sewage 


\section{Introduction}

From about 100 years ago when the relationship between bacteria and pathogenic microbes and prevalence of disease was discovered, efforts were directed toward clearing polluted waters. In other words, technology of water and wastewater treatment evolved in its present form as a result of advances in biology and medical sciences. Concentration and paying attention to this technology began when gradually and for the sake of preventing pollution of natural water resources-specifically rivers-entrance of wastewater to these resources was forbidden. These preventions demanded treatment of wastewater and development of its methods. As time passed and especially after WWII, as a result of development of cities and industries, threat of environmental pollutions and consequently, demands for wastewater treatment increased significantly and at the same time, many methods for treatment of wastewater were suggested and used [1].

In cargo terminals, with respect to problems faced by systems of wastewater treatment and sewage, available systems of terminals are not in appropriate conditions. The aim of present paper is to assess the current conditions of wastewater sewage in cargo terminals of shorelines by putting emphasis over that of Bandar Abbas and presenting appropriate solutions for systems of wastewater treatment and sewage. For this, it is attempted to achieve minor goals such as determination of the level of water consumption and produced wastewater in cargo terminals, determination of specifications and sources of production of wastewater in terminals based on introduction of available utilities, determination of various methods of wastewater sewage in small communities and so on.

\section{A Brief Literature Review}

During 1957-1961, plan of the first stage of urban sewage network in Isfahan was implemented in 84 km length. By establishment of the network in accordance with technical specifications, problems were solved. In 1966, first wastewater treatment plant with a capacity approaching to 90,000 people was established in southeastern Isfahan [2]. Regular planning for rural wastewater treatment systems in Finland started since 1950.

For treatment of wastewater, first, canebrakes and then oxidation pools and various active slurry systems were used. Further, in rural areas of Australia, artificial canebrakes are used as a result of having benefits such as socially acceptance, simple and cheap construction are used [3]. Masi et al. (2007) constructed wetlands for the Mediterranean countries. In fact they provide hybrid systems for water reuse and sustainable sanitation [4]. Lenz et al. 2010 provided a verification of the efficiency of chemical disinfection and sanitation measures in inbuilding distribution systems [5]. Islam et al. (2011) provided a method for purification of household water using a novel mixture reduces diarrhoeal disease in Matlab, Bangladesh [6]. Pradeep and Anshup (2009) presented a critical review about noble metal nano-particles for water purification [7]. Fuentesa et al. (2012) showed results from a first autonomous optically adapted photo catalytic-photovoltaic module for water purification [8]. Kar and Tewari (2013) provided applications of Nanotechnology for domestic water purification [9]. Tonon et al. (2015) evaluated a wastewater treatment system combining anaerobic filters and sand filters, focusing on the suitability of such system to remove solids, organic matter, phosphorus, and pathogens, as well as the nitrification efficiency of the sand filters employed [10]. Gholizadeh Aghoyeh et al. (2014) designed dual column water purification system for industrial gamma irradiator based of PUROLITE ${ }^{\circledR}$ resins [11]. Udom et al. (2014) provided a simple photolytic reactor employing Ag-doped $\mathrm{ZnO}$ nanowires for water purification [12]. Rosenberg and Rodríguez (2008) presented an optimal water purification system using low grade waste heat in an absorption heat transformer [13]. Duff and Hodgson (2005) provide a new passive solar water pasteurization system based on density difference flow principles has been designed, built and tested [14].

\section{Terminal}

Cargo terminal is a place at the vicinity of cities and main centers of freight for the purpose of making consolidation and concentration as well as organization of products shipment and providing services for drivers, product owners and agencies of product shipment and includes equipment, facilities and services such as offices of companies and product shipment institutions, truck parking and all services corresponding to marketing as well as navigation and leading of road transportation fleet [15]. In general, one of the characteristics of cargo terminals is that these places have service spaces such as parking, mosque and prayer rooms, WCs, dormitories for drivers, emergency and clinic and so on. 
Form 1 - 4: specifications of conditions of water and wastewater treatment and sewage system of Bandar Abbas cargo terminal

Method of supplying water: water well $\square$ urban water system $\square$ tanker

Method of storing water: concrete tanker $\square$ aerial tanker $\square$

Level of water consumption in $\mathrm{m}^{3} /$ day: 435

Level of produced wastewater in $\mathrm{m}^{3} /$ day: 304

Wastewater collection system: has

Treatment of wastewater: absorbing well $\square$ septic tanker $\square$ septic tankers $\square$ active slurry

Method of wastewater sewage:

Discharge of septic tanker outside terminal

Discharge of septic tanker with absorption well

Discharge of treatment system wastewater to absorption well

Waters discharged in adjacent lands

Sewed wastewater is chlorinated: yes $\square$ no

\section{Geographic and Natural Situations of Research Provinces}

Hormozgan Province: this province with about 71,193 $\mathrm{km}^{2}$ area is located between Zagros mountain range in north and Persian Gulf and Oman Sea in south. His province consists land area and two main islands; Qeshm and Hormoz.

Bushehr Province: with an area approaching 23,168 $\mathrm{km}^{2}$ is like a narrow stripe extending from west from Khuzestan province to east to Hormozgan province.

Khuzestan Province: with an area as much as $63,213 \mathrm{~km}^{2}$, this province extends from southern part of Zagros mountain range for Persian Gulf in its south.

Sistan and Baluchistan Province: with 178,431 $\mathrm{km}^{2}$ area, this is the largest province of Iran which approaches from north to Southern Khorasan and Afghanistan, from south to Oman Sea, from east to Afghanistan and Pakistan and from west to Kerman and Hormozgan [16].

\section{Wastewater and Its Treatment}

If water loses its quality for specific uses, it becomes wastewater. Therefore, wastewater is water which is used and throughout this process, many suspended particles and soluble ones are added to it [1]. Types of wastewaters depend upon their form, origin and specifications and their specifications are classified into domestic, industrial and ground level wastewaters.

In general, the purpose of treating wastewater is to maintain healthy conditions for human life, keeping environment clean and recovery of wastewater. Stages of wastewater treatment are preliminary stage including physical purification by removal of garbage and deposition of suspended particles, second stage or secondary purification includes biological purification through aeration and using bacteria available in wastewater or which secondary equipment of purification and demanding more energy and costs. Finally, third stage of wastewater treatment includes clarification and complementary purifications [17]. Further, methods of wastewater treatment as classified into three types:

1) Mechanical or physical treatment: it is comprised of a sequence of processes in which physical or mechanical properties are used for separation of suspended particles of wastewater.

2) Biological treatment: is performed using alive bacteria referred to as aerobic or anaerobic microbes for purification of wastewaters. Carrick of biological purification is the intensification of a reaction which occurs in environment naturally; that is, through providing a suitable environment for growth and proliferation of aforesaid bacteria, time of natural treatment which may last for a few days is shortened to a few hours [1].

3) Chemical treatment: basis of the chemical treatment is to use chemicals in treatment of wastewater. In wastewater treatment plants, chemicals can be used for affecting insoluble, colloid and soluble materials in wastewater. In general, factors contributing to selection of treatment method are: quality and quantity of wastewater, environmental conditions and changes in temperature in various seasons, facilities and limitations of treatment plant with respect to space and topography, level of intended treatment according to condition of wastewater and or the method of sewing treated wastewater, economic conditions with respect to initial investment and annual utilization cost and environmental conditions. 
Systems of wastewater treatment and sewage in small communities lack systems of wastewater collection and there are various types of communities having wastewater collection. In communities which lack a system of wastewater collection, wastewater is treated and sewed in in-place systems. However, in communities which have wastewater collection system, it is necessary to transfer collected wastewater to treatment place and then sew it after treatment and non-centralized treatment plants as much as possible and in some cases in which it is not practical to collect wastewater in a non-centralized manner, regions and towns are investigated and many non-centralized systems can be used. Some of the benefits of using non-centralized systems are low health and environmental affective impacts, reduction and removal of pumping stations, possibility of easy extension and so on. In general, methods of wastewater treatment in small communities are as follows:

1) Septic tanks and sandy absorption trenches: in this method, septic tank wastewater enters a perforated pipe which is embedded inside sandy trenches.

2) Tank system with series distribution of wastewater in absorption trenches: in this method, outgoing wastewater of septic tank enters first one of the absorption tanks and then its overflow enters another trench through falling box. Falling boxes are used for system inspection and level of trenches discharge is controlled. Filling out of trenches is performed by means of gravity force.

3) Septic tanks and absorption pools: In this method, output of septic tank enters concrete or arched plastic pools directly which are opened from bottom. These pools act as an underground tank which stores wastewater and wastewater is absorbed by soil from bottom of the pool and is purified.

4) Septic tank with intermittent trenches: in this system, trenches are divided into two parts; active and standby leading to improvement in productivity of the system. Change of outlet path of septic tank is possible for intermittency of performance of trenches by means of valves which are embedded in valve boxes.

5) Septic tank and distribution of its output using pump in absorption trenches. In this method, output of septic tank is spread among trenches by means of a pump or siphon under pressure and uniformly. This action results in spreading wastewater in a wider area and air exchange level with soil will be higher. This method is used mainly in conditions in which there are more wastewater flows or in places where it is not possible for wastewater to move under gravity force. Pressure is controlled mechanically or manually for control of the flow of each trench.

6) Septic tank with shallow trenches: in this method, output of septic tank is pumped to perforated pipes having small diameter which are located in shallow trenches.

\section{Wetland}

Wetland refers to places which are placed under water periodically with sufficient frequency and depth for growth of plants which are adapted to life in saturated soil. In these circumstances, transfer of oxygen from atmosphere to soil is slowed and soil is anaerobic except in a few millimeters of its surface. Pretreatment is one of the issues corresponding to wetland.

In United States, primary pretreatment, minimum equivalent of primary treatment or septic tank, Imhoff tank, pool, primary treatment or similar systems of reducing concentration of solid particles which are decomposed easily are used. These materials can accumulate in inlet of wetland and lead to obstruction, smell and undesired consequences on plants of the region. Moreover, plan of utilization and maintenance of wetlands includes planning for discharge and control of flow, circulation among cells, management of plants, clearing and maintenance of structures, control of insects and wildlife considerations.

\section{System Monitoring}

Programs of monitoring system of artificial wetland must be comprehensive and complete and must cover all main and important elements and parameters such as flow monitoring, monitoring of water quality inside and outside wetland flow, monitoring of plants, sampling of fauna of wetland [18].

\section{Materials and Methods}

To evaluate the current conditions of wastewater treatment and sewage in cargo terminals of shorelines of Bandar Abbas, Bushehr, Chabahar and Imam Khomeini Harbor as well as providing appropriate solutions for treatment and sewage of wastewater in these terminals by emphasis on terminal of Bandar Abbas, this research is 
carried out based on following cases:

1) Field observation of current conditions of wastewater sewage and treatment systems of in Bandar Abbas, Bushehr, Chabahar and Imam Khomeini Harbor terminals.

2) Determination of general characteristics of terminals including terminal area and location and utilities, water resources, as well as introduction of specifications of wastewater treatment and sewage.

3) Investigation and determination of geographical location and natural conditions of terminals in Bushehr, Khuzestan, Hormozgan and Sistan and Baluchestan provinces.

4) Investigation of history of qualitative tests corresponding to evaluation of efficiency of systems of wastewater treatment and sewage in aforesaid terminals.

5) Assessment of efficiency of systems of wastewater treatment and sewage of terminals, in-place inspection, preparation of form of specifications corresponding to conditions of system of water and wastewater treatment and sewage, periodic sampling and quality control with evaluation parameters including BOD, COD, $\mathrm{pH}$ and TSS.

6) Testing wastewater periodically and in various seasons as instantaneous sampling from inlet and outlet of the system of wastewater treatment and sewage using active slurry method in Bandar Abbas and same number of samples in inlet and outlet of septic tanks of other terminals in Bushehr, Chabahar and Imam Khomeini Harbor.

7) Method of sampling and performing tests according to instruction of the book "Standard Methods for the Examination of Water and Wastewater".

8) Processing and analysis of experimental data and comparison with standards of environment protection organization. In this stage, after collecting results of tests, aforesaid qualitative parameters in inlet and outlet of the sewage system of terminals are summarize in a table using Excel software.

9) Investigation and determination of current conditions of systems of wastewater treatment and sewage in small communities such as cargo terminals.

10)Presenting results of investigation of current conditions of systems of wastewater treatment and sewage for each terminal and modifying recommendations regarding performance and utilization of available systems and due to climatic similarities in terminals as well as quality of the produced wastewater, appropriate solution is provided.

\section{Results}

In this section, for each of the current conditions of systems of water and wastewater of research terminals, quality of inlet and outlet wastewater and efficiency of the wastewater treatment and sewage in cargo terminals of Bandar Abbas, Bushehr, Chabahar and Imam Khomeini Harbor for each season is summarized in tables as results of laboratory quality assessments. It must be noted that level of water consumption according to average consumption of terminal is estimated using consumption periods of 2005 and according to waster to wastewater conversion factors provided in scientific references for flow of produced wastewater and because of horizontal extension of available utilities, conversion factor of terminal was set as 0.7 [2]. The results can be found in the Table 1 and Table 2.

\section{Conclusions}

Results presented above are in general related to current conditions of systems of wastewater treatment and sewage in terminals of Bandar Abbas, Bushehr, Imam Khomeini harbor and Chabahar from which following conclusions can be drawn: based on evaluated parameters, obtained results correspond to quality of wastewater and efficiency of the sewage system of terminals and comparison of them with standards of environmental protection regarding quality of wastewater and sewage of wastewater which are presented by Figures 1-4.

Studying the presented tables and diagram corresponding to comparison and qualitative evaluation of qualitative parameters of wastewater in terminals is summarized as follows: results of assessment of qualitative parameters of wastewater of Bandar Abbas terminal reveals that value of BOD during various seasons varies from $263 \mathrm{mg} / \mathrm{l}$ in autumn to $383 \mathrm{mg} / \mathrm{l}$ in summer. This value for BOD of wastewater is $119 \mathrm{mg} / \mathrm{l}$ in spring and 293 $\mathrm{mg} / \mathrm{l}$ in winter. Regarding the value of COD, this parameter varies from $522 \mathrm{mg} / \mathrm{l}$ in autumn to $986 \mathrm{mg} / \mathrm{l}$ in spring. This range for COD of wastewater varies from $227 \mathrm{mg} / \mathrm{l}$ in spring to $896 \mathrm{mg} / \mathrm{l}$ in winter. Measurement of TSS illustrated that this parameter changes from $222 \mathrm{mg} / \mathrm{l}$ in spring to $382 \mathrm{mg} / \mathrm{l}$ in winter. This value for 
Table 1. Results of tests for determination of quality of inlet and outlet wastewater of the system of wastewater treatment of cargo terminals in 2005-6 (Author Findings).

\begin{tabular}{|c|c|c|c|c|c|c|c|c|c|c|c|}
\hline & & \multicolumn{2}{|c|}{ BOD (mg/l) } & \multicolumn{2}{|c|}{ COD (mg/l) } & \multicolumn{2}{|c|}{ TSS (mg/l) } & \multicolumn{2}{|c|}{ pH } & \multicolumn{2}{|c|}{$\mathrm{T}\left({ }^{\circ} \mathrm{C}\right)$} \\
\hline & & Inlet & Outlet & Inlet & Outlet & Inlet & Outlet & Inlet & Outlet & Inlet & Outlet \\
\hline \multirow{8}{*}{ 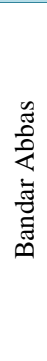 } & Spring & 305 & 190 & Inlet & Outlet & Inlet & Outlet & Inlet & Outlet & Inlet & Inlet \\
\hline & Summer & 327 & 177 & 693 & 359 & 283 & 209 & 7.63 & 7.57 & 26.2 & 693 \\
\hline & Autumn & 381 & 240 & 726 & 366 & 259 & 218 & 7.7 & 7.6 & 27.62 & 726 \\
\hline & Winter & 320 & 242 & 653 & 553 & 297 & 158 & 7.75 & 7.62 & 27.84 & 653 \\
\hline & Max & 381 & 242 & 672 & 493 & 308 & 196 & 7.78 & 7.56 & 24.76 & 672 \\
\hline & Min & 305 & 177 & 726 & 553 & 308 & 218 & 8 & 8 & 28 & 726 \\
\hline & Average & 333 & 212 & 653 & 359 & 259 & 158 & 8 & 8 & 25 & 653 \\
\hline & St. deviation & 71.7 & & 688 & 443 & 257 & 195 & 8 & 8 & 27 & 688 \\
\hline \multirow{8}{*}{ 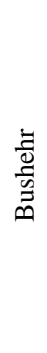 } & Spring & 268 & 283 & 145.8 & & 51.7 & & 0.1 & & 1.3 & 145.8 \\
\hline & Summer & 243 & 213 & 584 & 489 & 293 & 276 & 7.67 & 7.56 & 23.46 & 584 \\
\hline & Autumn & 296 & 273 & 541 & 461 & 221 & 197 & 7.8 & 7.75 & 25.76 & 541 \\
\hline & Winter & 234 & 228 & 497 & 428 & 318 & 236 & 7.55 & 7.67 & 26.84 & 497 \\
\hline & Max & 296 & 283 & 587 & 486 & 243 & 183 & 7.67 & 7.56 & 23.17 & 587 \\
\hline & Min & 234 & 213 & 587 & 489 & 318 & 276 & 8 & 8 & 27 & 587 \\
\hline & Average & 260 & 249 & 497 & 428 & 221 & 183 & 8 & 8 & 23 & 497 \\
\hline & St. deviation & 29.4 & & 552 & 466 & 269 & 223 & 8 & 8 & 25 & 552 \\
\hline \multirow{8}{*}{ 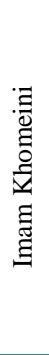 } & Spring & 320 & 224 & 56.9 & & 46.9 & & 0.1 & & 1.5 & 56.9 \\
\hline & Summer & 297 & 193 & 623 & 436 & 318 & 267 & 7.65 & 7.82 & 26.13 & 623 \\
\hline & Autumn & 276 & 243 & 589 & 394 & 313 & 237 & 7.73 & 7.56 & 27.07 & 589 \\
\hline & Winter & 262 & 218 & 563 & 482 & 321 & 286 & 7.81 & 7.5 & 26.34 & 563 \\
\hline & Max & 320 & 243 & 541 & 482 & 293 & 217 & 7.08 & 7.47 & 24.06 & 541 \\
\hline & Min & 262 & 193 & 623 & 482 & 321 & 286 & 8 & 3 & 27 & 623 \\
\hline & Average & 289 & 220 & 541 & 394 & 293 & 217 & 8 & 7 & 24 & 541 \\
\hline & St. deviation & 42.7 & & 579 & 444 & 311 & 252 & 8 & 3 & 26 & 579 \\
\hline
\end{tabular}

Table 2. Results of tests for determination of quality of inlet and outlet wastewater of the system of wastewater treatment of Bandar Abbas terminal in various times (Author Findings).

\begin{tabular}{|c|c|c|c|c|c|c|c|c|c|c|c|c|c|}
\hline \multirow{2}{*}{ No. } & \multirow{2}{*}{ Date } & \multicolumn{2}{|c|}{ BOD (mg/l) } & \multicolumn{2}{|c|}{ COD (mg/l) } & \multicolumn{2}{|c|}{ TSS (mg/l) } & \multicolumn{2}{|c|}{ pH } & \multicolumn{2}{|c|}{$\mathbf{T}\left({ }^{\circ} \mathrm{C}\right)$} & \multicolumn{2}{|c|}{ Chlorination } \\
\hline & & Inlet & Outlet & Inlet & Outlet & Inlet & Outlet & Inlet & Outlet & Inlet & Outlet & No & Yes \\
\hline 1 & 340 & 283 & 693 & 570 & 280 & 197 & 7.78 & 7.6 & 29.2 & 28.7 & * & & 340 \\
\hline 2 & 378 & 165 & 816 & 263 & 317 & 141 & 7.5 & 7.8 & 28.4 & 27.6 & * & & 378 \\
\hline 3 & 263 & 196 & 523 & 548 & 331 & 213 & 7.81 & 7.55 & 27.1 & 26.7 & $*$ & & 263 \\
\hline 4 & 328 & 268 & 713 & 383 & 228 & 119 & 7.76 & 7.67 & 27.6 & 27.1 & * & & 328 \\
\hline 5 & 293 & 286 & 538 & 596 & 352 & 241 & 7.8 & 7.49 & 25.5 & 25.1 & $*$ & & 293 \\
\hline 6 & 341 & 273 & 694 & 564 & 258 & 194 & 7.75 & 7.8 & 24.1 & 23.6 & * & & 341 \\
\hline 7 & 284 & 162 & 561 & 523 & 382 & 253 & 7.76 & 7.51 & 26 & 25.3 & * & & 284 \\
\hline 8 & 321 & 293 & 768 & 384 & 291 & 168 & 7.8 & 7.5 & 22.5 & 21.8 & $*$ & & 321 \\
\hline 9 & 361 & 196 & 799 & 398 & 260 & 124 & 7.81 & 7.54 & 25.7 & 24.6 & * & & 361 \\
\hline 10 & 263 & 197 & 620 & 383 & 272 & 182 & 7.5 & 7.2 & 26.7 & 26.2 & $*$ & & 263 \\
\hline 11 & 289 & 214 & 548 & 431 & 299 & 363 & 7.76 & 7.5 & 27 & 26.3 & * & & 289 \\
\hline 12 & 383 & 119 & 986 & 387 & 222 & 122 & 7.67 & 7.91 & 27.8 & 27 & $*$ & & 383 \\
\hline 13 & 318 & 196 & 694 & 227 & 298 & 137 & 7.61 & 7.74 & 27.9 & 26.7 & * & & 318 \\
\hline 14 & 276 & 228 & 621 & 371 & 328 & 243 & 7.65 & 7.5 & 28.7 & 27.6 & $*$ & & 276 \\
\hline 15 & 364 & 128 & 862 & 398 & 321 & 183 & 7.8 & 7.5 & 26.2 & 25.7 & * & & 364 \\
\hline 16 & 270 & 183 & 592 & 318 & 293 & 252 & 7.6 & 7.8 & 26.8 & 26.2 & * & & 270 \\
\hline 17 & 347 & 221 & 726 & 384 & 272 & 221 & 7.7 & 7.5 & 26.2 & 25.7 & * & & 347 \\
\hline
\end{tabular}




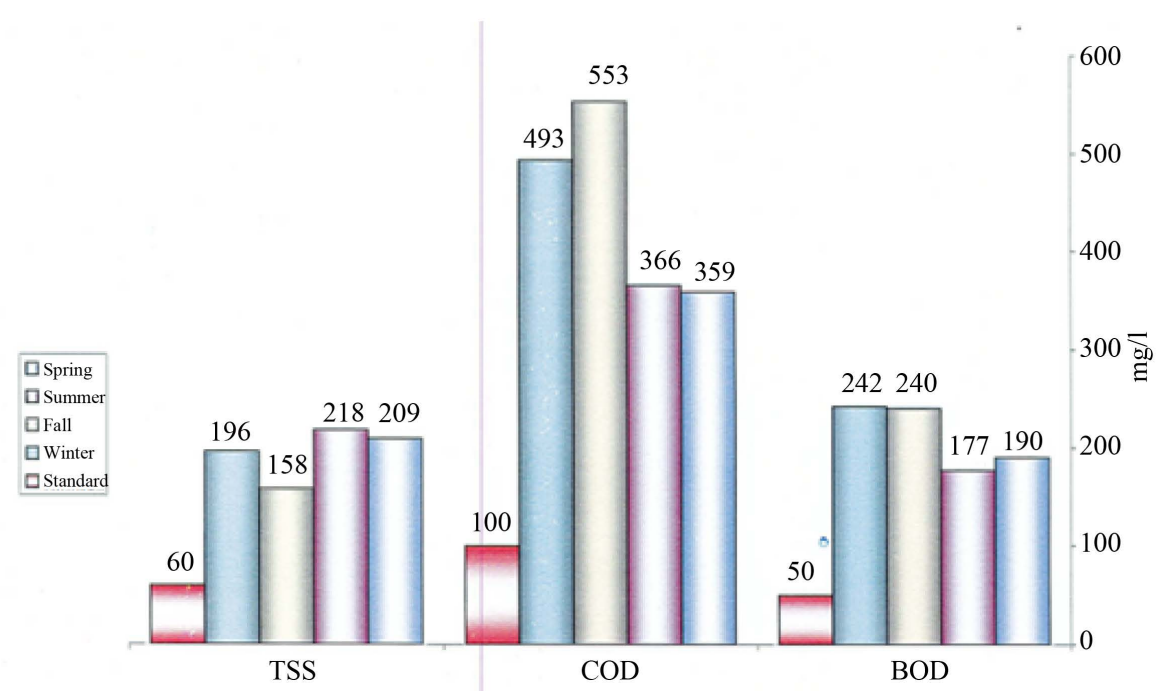

Figure 1. Seasonal comparison of the quality of outlet wastewater of Bandar Abbas terminal (Author Findings).

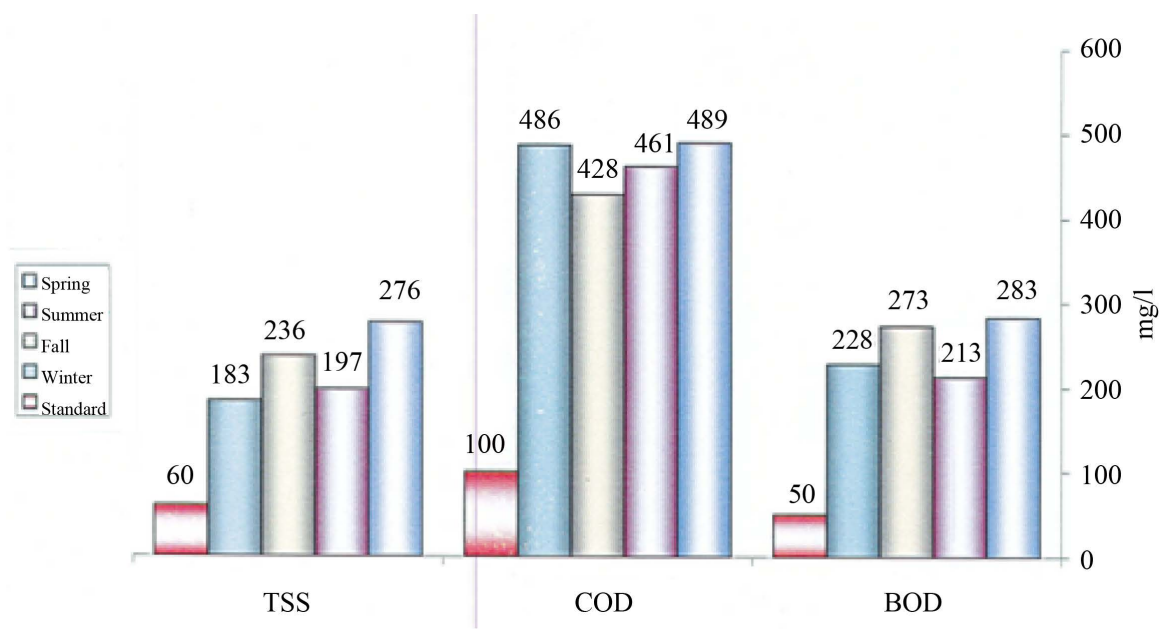

Figure 2. Seasonal comparison of the quality of outlet wastewater of Bushehr terminal (Author Findings).

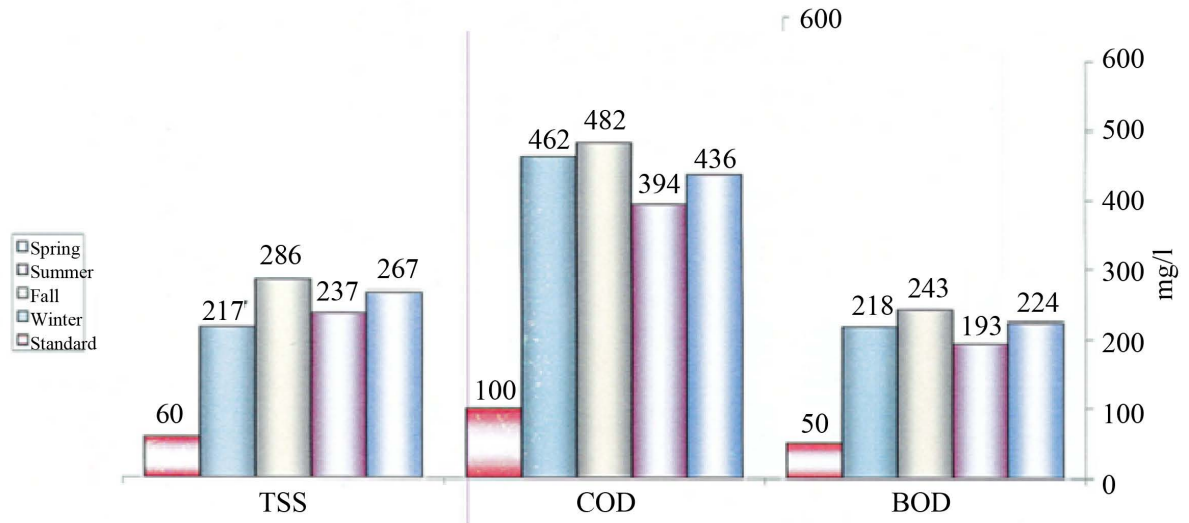

Figure 3. Seasonal comparison of the quality of outlet wastewater of Imam Khomeini terminal (Author Findings). 


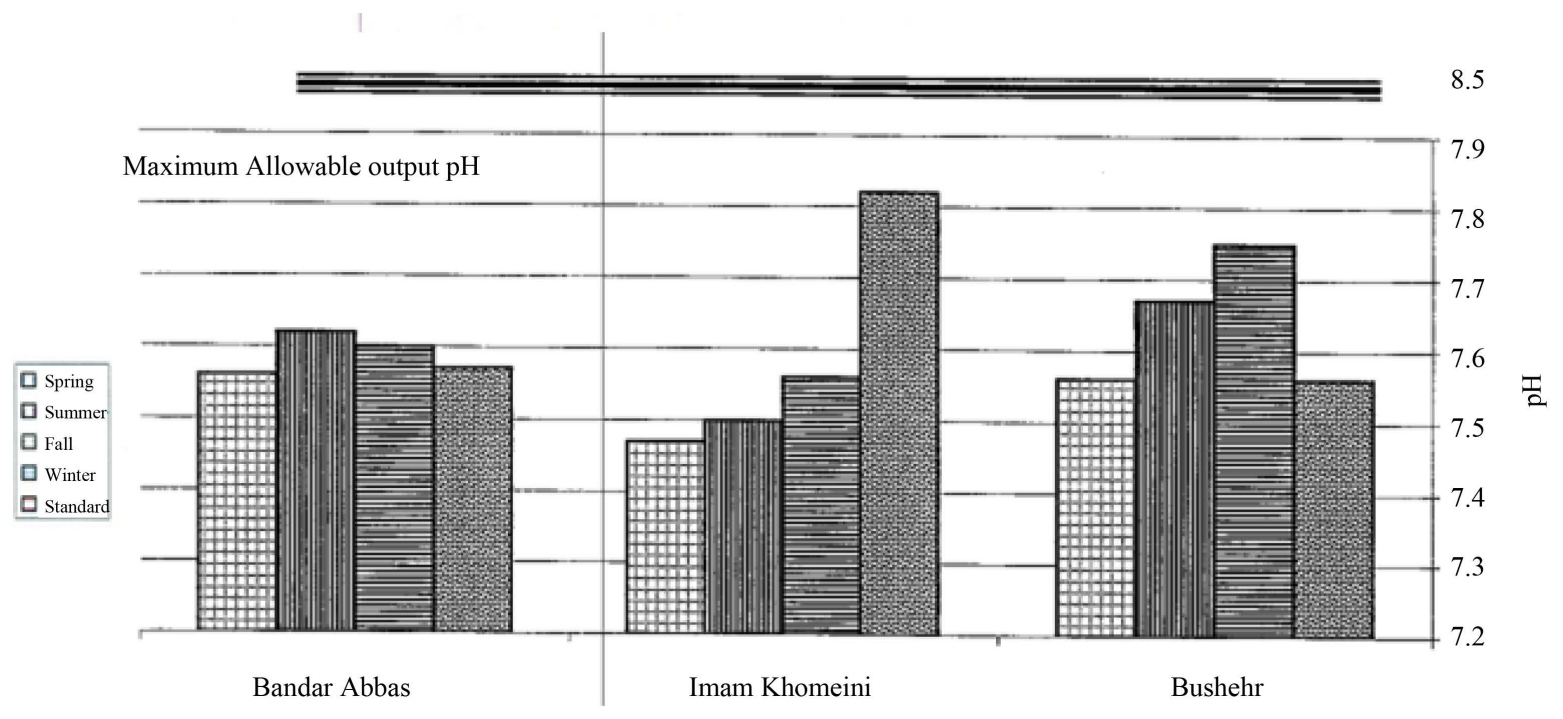

Figure 4. Seasonal comparison of output sewage pH (Author Findings).

wastewater varies among $119 \mathrm{mg} / \mathrm{l}$ in autumn to $363 \mathrm{mg} / \mathrm{l}$ in spring. Moreover, results of measurement of qualitative parameters in wastewater of Bushehr terminal revealed that value of BOD during various seasons varies from $243 \mathrm{mg} / \mathrm{l}$ in summer to $296 \mathrm{mg} / \mathrm{l}$ in autumn. This value for wastewater varies from $213 \mathrm{mg} / \mathrm{l}$ in summer to $283 \mathrm{mg} / \mathrm{l}$ in spring. COD varies from $497 \mathrm{mg} / \mathrm{l}$ in autumn to $587 \mathrm{mg} / \mathrm{l}$ in winter. The value of COD for wastewater varies from $428 \mathrm{mg} / \mathrm{l}$ in autumn to $489 \mathrm{mg} / \mathrm{l}$ in spring.

Measurement of TSS reveals that this value changes from $221 \mathrm{mg} / \mathrm{l}$ in summer to $318 \mathrm{mg} / \mathrm{l}$ in winter. Same value for wastewater varies from $197 \mathrm{mg} / \mathrm{l}$ in summer to $276 \mathrm{mg} / \mathrm{l}$ in spring. By studying the results of qualitative parameters of wastewater in studied terminals, it was revealed that highest value of BOD for output wastewater in spring was as much as $283 \mathrm{mg} / \mathrm{l}$ in Bushehr terminal and lowest value corresponds to Bandar Abbas terminal as much as $177 \mathrm{mg} / \mathrm{l}$. Regarding COD in outlet wastewater, it was discovered that highest value corresponds to autumn as much as $553 \mathrm{mg} / \mathrm{l}$ in outlet wastewater of Bandar Abbas terminal and lowest value is for spring season of the same terminal as much as $395 \mathrm{mg} / \mathrm{l}$. Moreover, by comparison of values of TSS of outlet terminals, it was revealed that highest value corresponds to outlet wastewater of Imam Khomeini Harbor in autumn as much as $286 \mathrm{mg} / \mathrm{l}$ and lowest value corresponds to autumn season as much as $158 \mathrm{mg} / \mathrm{l}$ in outlet wastewater of Bandar Abbas terminal.

According to tables of laboratory tests results and diagrams and comparison of evaluated parameters with standards of environmental protection organization regarding discharge and sewage of wastewater to groundwater which are summarized in Table 1, it was revealed that seasonal values of COD, TSS and BOD in outlet wastewater of treatment and sewage systems are considerably different from corresponding standard values. Moreover, by investigation of $\mathrm{pH}$ of outlet wastewater with standard values, it was found out that $\mathrm{pH}$ of outlet wastewater of terminals in various seasons are in range recommended by standard. According to carried out research and comparison of results obtained from evaluation of qualitative parameters of cargo terminals with treatment and sewage standards of environmental protection organization, it can be seen that aforesaid values are not compatible with relevant standards. Finally, due to unsuitable conditions of maintenance and utilization of systems of wastewater treatment and sewage in studied terminals owing to lack of repair and maintenance system on one hand and additional costs imposed by consumption of repair power, replacement of electrical and mechanical parts and accessories, providing simple solutions which demand no skilled workers and require lower power and energy, maintenance and repair costs and at the same time, have appropriate efficiency for treatment of sewage are recommended as the first priority of establishment of new cargo terminal in Bandar Abbas using methods such as artificial canebrakes for treatment and sewage of wastewater. Furthermore, assessment of the possibility of establishing wastewater branches in regions close to urban wastewater collection network of cities like Bushehr by transportation organization of corresponding province and in coordination with water and wastewater organization of the province is recommended. 


\section{References}

[1] Monzavi, M.T. (1992) Wastewater Treatment. Vol. 2, Tehran University Press, Tehran, 1-45.

[2] Yousefi (1997) Treatment of Wastewater in Developing Countries and Appropriate Treatment Systems for Small Communities. School of Health and Institute of Health Researches.

[3] Dgard, H. (1993) Design and Operation of Small Wastewater Treatment Plants, w.s.t, 28.10.

[4] Masia, F. and Martinuzzi, N. (2006) Constructed Wetlands for the Mediterranean Countries: Hybrid Systems for Water Reuse and Sustainable Sanitation, MEDAWATER. International Conference on Sustainable Water Management, Rational Water Use, Wastewater Treatment and Reuse, Marrakech, 8-10 June 2006.

[5] Lenz, J., Linke, S., Gemein, S., Exner, M. and Gebel, J. (2010) Verification of the Efficiency of Chemical Disinfection and Sanitation Measures in In-Building Distribution Systems. International Journal of Hygiene and Environmental Health, 213, 198-203. http://dx.doi.org/10.1016/j.ijheh.2010.04.006

[6] Islam, M.S., Mahmud, Z.H., Uddin, M.H., Islam, K., Yunus, M., Islam, M.S., Nair, G.B., Endtz, H.P. and Sack, D.A. (2011) Purification of Household Water Using a Novel Mixture Reduces Diarrhoeal Disease in Matlab, Bangladesh, Transactions of the Royal Society of Tropical Medicine and Hygiene, 105, 341-345. http://dx.doi.org/10.1016/j.trstmh.2011.03.003

[7] Pradeep, T. and Anshup (2009) Noble Metal Nanoparticles for Water Purification: A Critical Review. Thin Solid Films, 517, 6441-6478. http://dx.doi.org/10.1016/j.tsf.2009.03.195

[8] Fuentes, M., Vivar, M., Scott. J., Srithar, K. and Skryabin, I. (2012) Results from a First Autonomous Optically Adapted Photocatalytic-Photovoltaic Module for Water Purification. Solar Energy Materials and Solar Cells, 100, 216-225. http://dx.doi.org/10.1016/j.solmat.2012.01.020

[9] Kar, S. and Tewari, P.K. (2013) Nanotechnology for Domestic Water Purification. Nanotechnology in Eco-Efficient Construction, Materials, Processes and Applications, A Volume in Woodhead Publishing Series in Civil and Structural Engineering, 364-427.

[10] Tonon, D., Luiz Tonetti, A., Coraucci Filho, B. and Camargo Bueno, D.A. (2015) Wastewater Treatment by Anaerobic Filter and Sand Filter: Hydraulic Loading Rates for Removing Organic Matter, Phosphorus, Pathogens and Nitrogen in Tropical Countries. Ecological Engineering, 82, 583-589. http://dx.doi.org/10.1016/j.ecoleng.2015.05.018

[11] Gholizadeh Aghoyeh, R. and Khalafi, H. (2014) Design of Dual Column Water Purification System for Industrial Gamma Irradiator Based of PUROLITE ${ }^{\circledR}$ Resins. Annals of Nuclear Energy, 69, 90-96. http://dx.doi.org/10.1016/j.anucene.2014.02.006

[12] Innocent Udom, I., Zhang, Y., Ram, M.K., Stefanakos, E.K., Hepp, A.F., Elzein, R., Schlaf, R. and Goswami, D.Y. (2014) A Simple Photolytic Reactor Employing Ag-Doped ZnO Nanowires for Water Purification. Thin Solid Films, 564, 258-263. http://dx.doi.org/10.1016/j.tsf.2014.05.057

[13] Rosenberg, J.R. and Rodríguez, A.M. (2008) Optimal Water Purification Using Low Grade Waste Heat in an Absorption Heat Transformer. Desalination, 220, 506-513.

[14] Duff, W.S. and Hodgson, D.A. (2005) A Simple High Efficiency Solar Water Purification System. Solar Energy, 79, 25-32. http://dx.doi.org/10.1016/j.solener.2004.10.005

[15] Statistical Calendar of National Road Transportation (2004) Office of IT of Road Maintenance and Road Transportation.

[16] Ministry of Power (1991) Comprehensive Water Plan of Country. Climatology of Iran, 4.

[17] Matkov and Eddie (1995) Wastewater Engineering. Translated by Abrishamchi.

[18] Wetland Systems in Water Pollution Control Water Science and Technology. 29. 